\title{
Analysis on Occupational Self-Efficacy of Elementary Mathematics and Science Teachers
}

\section{Cahit Taşdemir}

Tatvan Vocational School, Bitlis Eren University, Bitlis, Turkey

\section{ABSTRACT}

In this study, the purpose is to analyze the self-efficacy beliefs of the elementary mathematics and science teachers according to a group of variables. For this purpose, "Teacher Occupational Self-Efficacy Scale" developed by Kahyaoğlu and Yangın (2007) and personal information form that is composed by the researcher are used as the data collection tool to measure the self-efficacy of teachers. The study is conducted in the spring semester of the 2016-2017 school year. The sample of the study consists of a total of 91 teachers, of which 44 are Elementary Mathematics Teacher and 47 are Science Teacher serving in public schools in Bitlis's Tatvan district. For the analysis of the collected data, the unpaired t-test and ANOVA were applied. According to the results of the analysis, it is found that occupational self-efficacy levels of prospective teachers are on "Very Efficient" level. In addition, it is determined that there are no statistically significant differences in mean scores of teachers' occupational self-efficacy beliefs in terms of gender, education type, and the graduated department but in terms of the types of high schools which they graduated from. Only this variable shows a statistically significant difference.

Keywords: Prospective mathematics teachers, self-efficacy, academic self-efficacy, teacher training
${ }^{*}$ Correspondence to Author:

Cahit Taşdemir

Tatvan Vocational School, Bitlis Eren University, Bitlis, Turkey

How to cite this article:

Cahit Taşdemir. Analysis on Occupational Self-Efficacy of Elementary Mathematics and Science Teachers. American Journal of Educational Research and Reviews, 2017,2:9.

\section{eSciencePublisher。}

eSciPub LLC, Houston, TX USA. Website: http://escipub.com/ 


\section{INTRODUCTION}

The most important element of the education system is the teacher and the success of the education system is basically depends on teachers' qualifications who will function the system. The teacher of the 21st century; has undertaken tasks of providing the education, classroom management assessment, reassurance, occupational mastery, community leadership and family membership. Accordingly, the teacher should manage the class properly, present the topic effectively, provide the education, assess objectively, have the knowledge, be supervising, have professional activities, follow professional ethics and should provide confidence (Saracaloğlu, 2006, as cited in; Saracaloğlu et al., 2013).

Teachers must have efficacy in certain areas to enable students to reach the desired level in education. The concept of the teacher efficacy which is commonly referred recently is a concept adopted by most of the educators since it does elaborate the skills of a prospective teacher who finished one's education explicitly (Kuran, 2002, pp. 253-278; as cited in; Kahyaoğlu ve Yangın, 2007).

Efficacy in the most general terms includes necessary knowledge, skills, and attitudes to effectively complete a work for individuals (Huyugüzel and Kesercioğlu, 2008, as cited in, Maraş Atabay et al., 2017). According to Ministry of Education (2006), the concept of efficacy refers to being able to complete a work or a task. The concept of efficacy states the existence of the positive features for completing the duties, and the absence of negative features that will impede achieving success in individuals (Açıkalın, 1994; as cited in, Maraş Atabay et al., 2017).

Self-efficacy belief is one of the most important factors that enables teachers to achieve their goals. Self-efficacy belief has been one of the major fields of study especially for experts working in the field of teacher training in recent years (Deniz, 2013; as cited in, Maraş Atabay et al., 2017). Perception of self-efficacy involves successful regulation and efficient application of cognitive, social, emotional and behavioural skills that are necessary to perform a task. Moreover, the perception of self-efficacy is not merely about the abundance of skills possessed by the person, but also what the person believes about what one can do with these skills (Bandura, 1977). The belief of selfefficacy also affects people's thinking mechanisms and emotional responses. Individuals with a high level of self-efficacy can be more comfortable and productive when coping with highly difficult works. Those who have low self-efficacy belief think as if works are more difficult than it is in reality. Such thoughts; narrows the perspective necessary for a person to solve the problem in an optimum manner while increasing anxiety and stress. Therefore the belief of self-efficacy strongly affects individuals the level of success (Pajares, 2002, as cited in; Üredi and Üredi, 2006).

In the literature review, it is observed that there are numerous research conducted on teachers' self-efficacy beliefs (Altunçekiç, Yaman and Koray, 2005; Erdem, 2008; Otacıoğlu, 2008; Senemoğlu, Demirel, Yağcı and Üstündağ, 2009; Taşkın and Hacıömeroğlu, 2010; Yaşar, Gültekin and Ersoy, 2006; Yılmaz and Çokluk Bökeoğlu, 2008; as cited in; Oğuz, 2012). There is a lot of research about what teacher competence are or what they should be. When some of these works are examined, (Sünbül, 2001; Lunenberg, 2002; Küçükahmet, 1999; Demirel, 1999; Erden, 1998, Sönmez, 2003; Şeker et al., 2005; as cited in; Maraş Atabay, et al., 2017). However, studies conducted on teachers' occupational self-efficacy are very few. This makes the studies on teachers' occupational self-efficacy more important. Therefore, it is projected that it will be an important contribution to literature through determination of beliefs of mathematics and science teachers occupational self-efficacy and the analysis of these beliefs in terms of certain variables in this study. 


\section{RESEARCH}

\section{The Objective of the Research}

The aim of this research is to examine the occupational self-efficacy of primary school mathematics and science teachers based on variables like gender, graduated department, high schools from which they graduated from and education type. In line with this purpose, responses to the following questions are sought.

1. What is the level of occupational selfefficacy of the teachers?

2. Does the occupational self-efficacy of the teachers show a significant difference according to gender, graduated department, high school which they graduated from and education type?

\section{METHOD}

\section{Research Design}

The relational screening model was used in the realization of the study. Screening model is a research approach aimed at describing a past or present situation as it is. (Karasar, 2002).

\section{Research Group}

The sample group of the study consist of 91 teachers in total, of which 44 are Primary School Mathematics teachers and 47 are Science teachers working in public schools located in Tatvan district of Bitlis province in the spring semester of the 2016-2017 academic year. $29.7 \%(\mathrm{~N}=27)$ of the teachers constituting the sample group of the study were females and $70.3 \%(\mathrm{~N}=64)$ were males. $48.4 \%(\mathrm{~N}=44)$ of the teachers were primary school mathematics teachers and $51.6 \%(\mathrm{~N}=47)$ were science teachers. In addition, it is observed that $51.6 \% \quad(\mathrm{~N}=47)$ of the teachers were Anatolian high school graduates, $33.0 \%(\mathrm{~N}=30)$ were general high school graduates, \% 3.3 $(\mathrm{N}=3)$ were vocational high school graduates and \% $12.1 \quad(\mathrm{~N}=11)$ were süper high school graduates.

Personal information form created by the researcher and "Teacher Occupational SelfEfficacy Scale" developed by Kahyaoğlu and Yangın (2007) were used as data collection tools in the study. The reliability coefficient of the scale (Cronbach Alpha) was calculated as .8998. The range of the scale is calculated by the formula ( $\mathrm{a}=$ array width/number of groups). In the scale created based on this; options and limits are described as "1,00-1,79=I am not efficient", "1,80-2,59 = I am somewhat efficient", "2,60- $3,39=1$ am moderately efficient ", "3,40-4,19=I am very efficient" and "4,20-5,00 = I am fully efficient". The Cronbach Alpha internal consistency coefficient for the reliability of the scale was found to be .85 in this study.

\section{Analysis of Data}

SPSS17.0 package program was used for statistical analysis of data collected with questionnaire form and within the scope of the general aim of the study. The total scores of each teacher participating in the survey were calculated according to the options they indicated and these scores were divided into the number of items and converted to points between 1 and 5 . Thus, it is ensured that the scores of the teachers are compared and their equivalence in the scale is easy to see. OneWay Analysis of Variance and Independent One-Sample T-Test were used in the analysis of the data. According to the result of homogeneity test of variance, the $p$-value was found as $0.510>0.05$. As a result, since the basic assumption of the variance analysis is provided, we can say that the results we obtained from analysis of variance are reasonable (Kalaycl, 2006, p.138). The Scheffe test was used to determine in which group the difference is in the case of the significance of $F$ value. The level of significance in the statistical analyzes was regarded as .05 .

\section{RESULTS}

\section{Data Collection Tools}


This part contains findings from the data collected within the scope of the study.

With the purpose of answering of the first subproblem of the study, the minimum, maximum, mean, and standard deviation scores of the teachers' occupational self-efficacy scores are given in Table-1.
When Table 1 is examined, the occupational self-efficacy average scores of the teachers is found as $(\bar{x}=3.93)$ and the standard deviation is found as $S=0.49$. The calculated score corresponds to "I am very efficient" level in the base scale.

Table 1. Occupational Self-Efficacy Scores Of The Teachers

\begin{tabular}{|c|c|c|c|c|c|}
\hline Variable & & Min. & Max. & $\overline{\bar{x}}$ & $s$ \\
\hline Occupational Self-Efficacy & 91 & 2,52 & 4.84 & 3,93 & 0,49 \\
\hline
\end{tabular}

With the purpose of answering second subproblem of the study, The results of the independent sample t-test performed in order to determine whether teachers' occupational selfefficacy shows significant differences according to gender were given in Table 2.

Table 2. T-test Results of Teachers' Vocational Self-Efficacy Scores According to Gender Variable

\begin{tabular}{lllllll}
\hline Gender & $\boldsymbol{N}$ & $\overline{\boldsymbol{x}}$ & $\boldsymbol{S}$ & $\boldsymbol{s d}$ & $\boldsymbol{t}$ & $\mathbf{p}$ \\
\hline Female & 27 & 3,97 & 0,48 & 89 &, 447 & .656 \\
Male & 64 & 3,92 & 0,50 & & & \\
\hline
\end{tabular}

According to Table 2, it was determined that the teachers' occupational self-efficacy score average does not show any significant difference according to gender $[\mathrm{t}(89)=, 447$, p>.05]. Therefore, it can be said that the gender variable has no significant effect on the teachers' occupational self-efficacy average scores. The average scores of female and male teacher candidates are very close to each other. It is seen that the average score of the

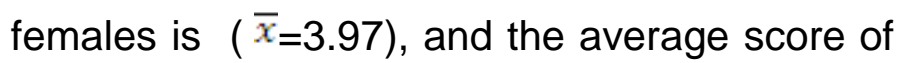
the males is ( $\left.\bar{x}_{=}=3.92\right)$.

The results, whether teachers' occupational self-efficacy shows significant difference according to the type of high school graduated, were presented in Table 3.

Table 3. Arithmetic Mean and Standard Deviation Results of the Teachers' Occupational Self-Efficacy Score Averages by High School Type

\begin{tabular}{l|rrl}
\hline Type Of High School & $\boldsymbol{N}$ & $\bar{x}$ & ss \\
\hline Anatolian High School & 47 & 3.95 & 0.31 \\
General High School & 30 & 3.78 & 0.71 \\
Vocational High School & 3 & 3.97 & 0.01 \\
Super High School & 11 & 4.26 & 0.28 \\
\hline Total & 91 & 3.93 & 0.49 \\
\hline
\end{tabular}

When Table 3 is analyzed, it is seen that teachers' occupational self-efficacy total average score is $\left(\bar{x}_{=}=3.93\right)$ based on the type of high school that they graduated. The average of teachers graduated from Anatolian High School was $(\bar{x}=3.95)$, General High School 
$(\bar{x}=3.78)$, Vocational High School $\left(\bar{x}_{=}=3.97\right)$ and Super High School ( $\bar{x}=4.26)$. According to these findings, the occupational self-efficacy average scores of the teachers who graduated from the Super High School are higher than the teachers who graduated from the other high schools. The results of the Scheffe test which is performed to test whether this difference is statistically significant or not is presented in Table-4.

\section{Table 4. Results of the ANOVA test on teachers' occupational self-efficacy beliefs according to the type of high school graduated}

\begin{tabular}{lclclcc}
\hline Source of & Sum of Squares Varience & sd & Means of Squares & $\mathbf{F}$ & $\mathbf{P}$ & Difference \\
\hline Between groups & 1.910 & 3 & 0.637 & 2.74 & .048 & $4-2$ \\
Within goups & 20.208 & 87 & 0.232 & & & \\
\hline
\end{tabular}

Total $22.118 \quad 90$

1.Anatolian High School, 2. General High School,3. Vocational High School, 4. Super High School

When table 4 was examined, it was determined that the teachers' occupational self-efficacy score average shows a significant difference according to types of high schools graduated [ $\left.F_{(3-87)}=2,74, p<0.05\right]$. According to the results of the Scheffe test which is performed to determine between which high school types this significant difference occurs, it is found that between the occupational self-efficacy scores of the teachers who graduated from the Super High School and the occupational self-efficacy scores of the teachers who graduated from the General High School, there was no significant difference in favor of the teachers who graduated from the Super High School.

Table 5 shows the results of whether teachers' occupational self-efficacy differ significantly according to education type.

Table 5. T-test Results of Teachers' Occupational Self-Efficacy Scores According to the Type of Education

\begin{tabular}{lllllll}
\hline Type of Education & $\boldsymbol{N}$ & $\bar{x}$ & $\boldsymbol{s}$ & $\boldsymbol{s d}$ & $\boldsymbol{t}$ & $\mathbf{p}$ \\
\hline Day-time Education & 73 & 3.92 & 0.54 & 89 & -.635 & .527 \\
Evening-time Education & 18 & 4.00 & 0.13 & & & \\
\hline
\end{tabular}

According to Table 5, it was determined that the teachers' occupational self-efficacy average scores do not show any significant difference according to the type of education $[\mathrm{t}(89)=-.635$, $p>$.05]. Hence, it can be concluded that the type of education variable does not have a significant effect on teachers' occupational self- efficacy averages. The average scores of the day-time and evening-time education are very close to each other. It is observed that the average score of the teachers who get day-time education is $(\bar{x}=3,92)$, and the average of the scores of teachers who get evening-time education is $(\bar{x}=4,00)$.

Table 6. T-test Results of Teachers' Occupational Self-Efficacy Scores According to the Graduated Department

\begin{tabular}{lllllll}
\hline Graduated Department & $\boldsymbol{N}$ & $\overline{\boldsymbol{C}}$ & $\boldsymbol{S}$ & $\boldsymbol{s d}$ & $\boldsymbol{t}$ & $\mathbf{p}$ \\
\hline Elementary Mathematics & 44 & 4.03 & 0.41 & 89 & 1.797 & .076 \\
Elementary Science & 47 & 3.84 & 0.55 & & & \\
\hline
\end{tabular}


The results, regarding whether teachers' occupational self-efficacy shows significant difference according to the type of education, were presented in According to Table 6, it was determined that the teachers' occupational selfefficacy score average does not show any significant difference according to graduated department $[t(89)=1.797, p>05]$. It is found that the occupational self-efficacy average score of the teachers who graduated from the Department of Mathematics Teaching is ( $\bar{x}=$ 4.03), while the occupational self-efficacy average score of the teachers who graduated from the Department of Science Teaching is $(\bar{x}=3.84)$. According to this finding, mathematics teachers' occupational self-efficacy scores are higher than science teachers' scores, but the difference is not significant.

\section{DISCUSSION AND CONCLUSION}

This section presents the results obtained through evaluation of the research findings and a discussion within the literature.

Teachers' occupational self-efficacy average score is determined as $(\bar{x}=3.93)$ and the standard deviation is $S=0.49$. It is found that this corresponds to the level of "I am Very efficient" based on the scale of calculated average scores. According to this finding it can be asserted that teachers' self-efficacy is high in general. This finding of the research, resembles with the results of Kahyaoğlu and Yangın's (2007) study of primary education teacher candidates, while it contradicts with the results of Maraş Arabay's et al., (2017) study of science teacher candidates.

It was determined that the teachers' occupational self-efficacy belief score average does not show any significant difference according to gender $[\mathrm{t}(89)=, 447, \quad \mathrm{p}>$.05]. According to this finding, it can be argued that gender variable has no significant effect on teachers' occupational self-efficacy belief. It is seen that the average score of the females is $(\bar{x}=3,97)$, and the average score of the males is $(\bar{x}=3,92)$. Female and male teachers' occupational average scores are very close to each other. According to the results of this study, female and male teachers perceive themselves almost similarly in terms of occupational self-efficacy. This finding of the research, resembles with the results of Kahyaoğlu and Yangın's (2007) study of primary education teacher candidates, while it contradicts with the results of Maraş Arabay's et al., (2017) study of science teacher candidates. In addition, Bulut (2009); Tanel, Şengören and Tanel (2007) determined that there is not a significant difference between attitudes of female and male teacher candidates towards their profession(as cited in, Maraş Atabay et al., 2017).

Another important finding of the research is that it was determined that the teachers' occupational self-efficacy score average show a significant difference according to types of high schools graduated $\left[F_{(3-87)}=2,74, p<\right.$ 0.05]. According to the results of the Scheffe test which is performed to determine between which high school types this significant difference occurs, it is found that between the occupational self-efficacy scores of the teachers who graduated from the Super High School and the occupational self-efficacy scores of the teachers who graduated from the General High School, there was no significant difference in favor of the teachers who graduated from the Super High School. Hence, it can be said that the occupational self-efficacy of the teachers who graduated from the Super High School are more efficient than the teachers who graduated from the General high schools. This finding of the research contradicts with the results of Kahyaoğlu and Yangın's (2007), Balım's et. al. (2009), Yarar ve Tekbıyık's (2009), and Maraş Arabay's et al., (2017) studies.

In the research, it has been determined that teachers occupational self-efficacy scores averages do not show any significant differences according to the variable of the 
education type $[\mathrm{t}(89)=-, 635, \mathrm{p}>.05]$. Hence, it can be concluded that the type of education variable does not have a significant effect on teachers' occupational self-efficacy averages. The average scores of the day-time and evening-time education are very close to each other. The average scores of the teachers who received normal education are determined as $(\bar{x}=3.92)$ and the average scores of the teachers received secondary education as $(\bar{x}=4.00)$ were found. While this finding of the research is parallel with the result of the study carried out on science teacher candidates by Maraş Atabay et al. (2017), it is contradictory to the results of the research with Kahyaoğlu and Yangın (2007) in primary school teacher candidates.

In this research, it was determined that the teachers' occupational self-efficacy score average does not show any significant difference according to graduated department. $[t(89)=1.797, \quad p>.05]$. The average of occupational self-efficacy score of teachers who graduated from mathematics teaching department is $\left(\bar{x}_{=} 4,03\right)$ and the average score of occupational self-efficacy of teachers who graduated from science teaching department $(\bar{x}=3,84)$. According to this finding, mathematics teachers' occupational self-efficacy scores are higher than science teachers' scores, but the difference is not significant. According to this result, it can be argued that the self-efficacy of teachers who graduated from mathematics teaching department and science teaching department is very close to each other. This result of the research contradicts the result of the research conducted by Kahyaoğlu and Yangın (2007).

As a result of the findings obtained in the study; it was found that the teachers' scores of occupational self-efficacy beliefs were in the level of "I am very competent" and that there is not any significant difference according to gender, type of education, graduated department, but there is a significant difference according to the variable of type of high school graduated. One reason for obtaining different findings in the study may stem from different socio-cultural backgrounds. According to Bandura (2002), rapid cultural and technological changes in society bring about significant changes in people's beliefs, values, social roles and behavioral styles. According to Kahyaoğlu and Yangın (2007), the qualities expected from teachers have also changed in the age of information, in which rapid change and development are experienced. Today, teachers are expected to demonstrate both the ability to use teaching methods and techniques at the optimum level, as well as the more modern classroom management that modern education requires and integrating them into learning environments.

In the forthcoming studies, it is possible to work on the occupational self-efficacy beliefs on teachers in different fields.

\section{References}

Balım, A.G., Kesercioğlu, T. Ve İnel, D. (2009). Fen öğretmen adaylarııın öz-yeterlilik inançları. Sosyal Bilimler Dergisi, ZKÜ, 235-252.

Bandura, A. (1977). Social Learning Theory. Englewood Cliffs NJ: Prentice Hall.

Bandura, A. (2002). Social cognitive theory in cultural context. Applied Psychology: An International Rewiew, 51(2), 269-290.

Kahyaoğlu, M. Ve Yangın, S. (2007). İlköğretim Öğretmen Adaylarının Mesleki Öz-yeterliklerine İlişkin Görüşleri. Kastamonu Eğitin Dergisi, 15(1), 7384.

Kalaycı, Ş. (2006). SPSS Uygulamalı Çok Değişkenli İstatistik Teknikleri( 2. Baskı), Ankara: Asil yayın Dağıtım Ltd. Şti.

Karasar, N. (2002). Bilimsel araştırma Yöntemi: Kavramlar, ilkeler, Teknikler, Ankara: 3A Araştırma Eğitim Danışmanlık Ltd.

Maraş Atabay, M., Bahadır, S. Ve Ergin, S. (2017). Fen Bilgisi Öğretmen adaylarının Mesleki Öz yeterliklerinin Analizi. Uluslararası Eğitim Bilimleri Dergisi, 10(4), 115-125.

Oğuz, A. (2012). Sınıf öğretmeni adaylarının akademik öz yeterlik ianançları, Anadolu Journal of Educational Sciences International, 2(2), 15-28. 
Saracaloğlu, A.S., Yenice, N., Özden, B. (2013). Fen

Bilgisi, Sosyal Bilgiler ve Sınıf Öğretmeni Adaylarının Öğretmen Öz-yeterlik Algılarının ve Akademik Kontrol Odaklarının incelenmesi, Pamukkale Üniversitesi Eğitim Fakültesi Dergisi, 34(11), 227250.

Üredi, I., Üredi L. (2006). İlköğretim 8. Sınıf Öğrencilerinin Öz-düzenleme Stratejileri ve Motivasyonel İnançlarının Matematik Başarısını Yordama Gücü. Mersin Eğitim Fakültesi Dergisi, 1, 250-260.

Yarar, S. Ve Tekbıyık, A. (2009). Öğretmen adaylarının öğretmenlik mesleğine yönelik sahip oldukları kişisel ve mesleki nitelikleri konusundaki algılarının incelenmesi. Rize Üniversitesi Eğitim Fakültesi Dergisi. 